\title{
PENGEMBANGAN PERANGKAT PEMBELAJARAN DENGAN PEMANFAATAN CERITA RAKYAT MELALUI MODEL PROJECT BASED LEARNING (PJBL) BERBASIS ROLE PLAYING DALAM MENINGKATKAN KETERAMPILAN SOSIAL PESERTA DIDIK
}

\author{
Lindra Nur Khanifah \\ Staf Pengajar Program Studi PGMI UNISDA Lamongan \\ lindra.10209@gmail.com
}

\begin{abstract}
Abstrak
Penelitian ini bertujuan untuk mendeskripsikan proses pengembangan perangkat pembelajaran, dimana mampu menghasilkan perangkat pembelajaran yang baik, dan mendeskripsikan keefektifan pembelajaran cerita rakyat di kelas $\mathrm{V}$ madrasah Ibtidaiyah dengan model Project Based learning (PjBL). Model pengembangan yang digunakan sebagai acuan adalah model Plomp. Model pengembangan ini meliputi lima fase yaitu fase investigasi awal, desain, face realisasi/ kronstruksi, face tes, evaluasi dan revisi, dan implementasi. Hasil pengembangan diuji dengan rancangan penelitian One Group Pretest-Postest Design.

Penelitian ini menghasilkan: 1) perangkat pembelajaran yang baik dengan kriteria validitas, dimana hasil penilaian validator terhadap perangkat pembelajaran mencapai $80 \%$; 2) pembelajaran IPS untuk mengajarkan cerita rakyat dalam kategori baik dengan kriteria kepraktisan yang diindikasikan dengan kemampuan guru mengelola pembelajaran berada dalam kategori baik dan keefektifan dengan indikator aktivitas peserta didik memenuhi kriteria efektif sesuai dengan waktu ideal dan ketuntasan hasil belajar secara klasikal mencapai 85\%; 3) model Project based learning untuk mengajarkan tentang cerita rakyat dengan kriteria (a) hasil belajar peserta didik tuntas dengan persentase ketuntasan secara klasikal 90\%, (b) kemampuan guru mengelola pembelajaran berada dalam kategori baik, (c) aktivitas peserta didik memenuhi kriteria efektif; (d) respon terhadap pembelajaran positif.
\end{abstract}

Kata Kunci : Model Project based learning, Metode Bermain peran

\section{PENDAHULUAN}

Ilmu Pengetahuan Sosial (IPS) merupakan pelajaran yang cukup komprehensif untuk menyikapi dan memecahkan masalah-masalah sosial sesuai dengan kadar kemampuan dan tingkat perkembangan peserta didik. Pada jenjang pendidikan sekolah dasar, pembelajaran IPS memfokuskan kajiannya kepada hubungan antar manusia dan proses membantu mengembangkan kemampuan dalam hubungan tersebut. Selain itu pembelajaran IPS di sekolah dasar merupakan wadah yang tepat untuk mengembangkan kemampuan sosial peserta didik. Dalam pembelajaran IPS peserta didik diajarkan dan dididik untuk memahami lingkungan dan kehidupan sosial sehari-hari agar mampu merespon permasalahan sosial secara efektif dan mampu membuat kehidupan sosial yang lebih bermakna. 
Pengetahuan, keterampilan dan sikap yang dikembangkan melalui kajian IPS ditujukan untuk mencapai keserasian dan keselarasan dalam kehidupan masyarakat. Pendidikan IPS sudah lama dikembangkan dan dilaksanakan dalam kurikulum-kurikulum di Indonesia, khususnya pada jenjang pendidikan sekolah dasar. Secara umum penguasaan pengetahuan sosial di sekolah dasar sudah cukup, tetapi penguasaan nilai dalam arti penerapan nilai, keterampilan sosial, dan partisipasi sosial hasilnya belum maksimal.

IPS adalah ilmu terapan mampu memberikan pengetahuan dan pemahaman kepada peserta didik untuk mempersiapkan diri memasuki dunia sosial secara nyata dan objektif serta menjadikan mereka sebagai warga negara yang baik yang berguna bagi masyarakat dan bangsanya serta mampu beradaptasi secara cepat karena mereka memiliki berbagai kompetensi sosial yang disajikan secara terpadu, sehingga ia dengan mudah dapat mengikuti perkembangan dan dinamika kehidupan masyarakat disekitarnya dengan kemampuan dan konsep yang dimilikinya. ${ }^{1}$ Sejalan dengan itu, menurut Somantri -sebagaimana yang dikemukakan Sapriya- pendidikan IPS adalah penyederhanaan atau adaptasi dari disiplin ilmu-ilmu sosial dan humaniora, serta kegiatan dasar manusia yang diorganisasikan dan disajikan secara ilmiah dan pedagogis/psikologis untuk tujuan pendidikan. $^{2}$

Banyak penyebab yang melatarbelakangi mengapa pendidikan IPS belum dapat memberikan hasil seperti yang diharapkan. Faktor penyebabnya dapat berpangkal pada kurikulum, rancangan, pelaksana, pelaksanaan, model pembelajaran, ataupun faktor-faktor pendukung pembelajaran yang lainnya. Dalam proses pembelajaran yang menyangkut materi, metode, media alat peraga dan sebagainya harus juga mengalami perubahan ke arah pembaharuan (inovasi). Dengan adanya inovasi tersebut, seorang guru dituntut untuk lebih kreatif dan inovatif, terutama dalam menentukan model dan metode yang tepat, karena hal ini sangat menentukan keberhasilan peserta didik terutama pembentukan kecakapan hidup (life skill) peserta didik yang berpijak pada lingkungan sekitarnya.

Model pembelajaran IPS yang diimplementasikan di sekolah dasar saat ini masih bersifat konvensional, seperti metode ceramah yang tidak menggunakan alat bantu, sehingga kegiatan pembelajaran hanya berpusat pada guru, jarang memberikan kesempatan kepada peserta didik untuk mengekspresikan pikiran dan perasaannya. Akibatnya timbul perbedaan individual peserta didik di dalam kelas, selain itu model pembelajaran yang diterapkan lebih menekankan pada aspek kebutuhan formal, tidak adanya interaksi antara peserta didik dengan peserta didik lainnya dan tidak ada kerjasama dalam kelompok belajar sehingga belum bisa mengembangkan potensi anak secara maksimal.

\footnotetext{
${ }^{1}$ Suhanadji. Pendidikan Ilmu Pengetahuan Sosial (Surabaya : UNESA PRESS, 2012),1.

${ }^{2}$ Sapriya. Pendidikan Ilmu Pengetahuan Sosial (Bandung :Media Karya, 2009), 11.
} 
Berdasarkan hasil observasi awal yang peneliti lakukan di Madrasah Ibtidaiyah Tuban, diperoleh informasi bahwa dalam pembelajaran IPS di kelas V pada beberapa hal sudah memperoleh keberhasilan. Diantaranya adalah walaupun guru menggunakan metode ceramah, peserta didik terlihat memperhatikan guru ketika proses pembelajaran dari awal guru melakukan apersepsi hingga guru melakukan evaluasi di akhir pembelajaran. Namun ada beberapa masalah yang ditemukan oleh penulis pada saat proses pembelajaran berlangsung, seperti; 1) guru masih cenderung mendominasi kegiatan pembelajaran, 2) guru hanya sebatas menggunakan papan tulis tidak menggunakan media pembelajaran lainnya untuk menunjang kegiatan pembelajaran, 3) guru belum memberikan reward kepada peserta didik yang aktif dalam kegiatan pembelajaran, 4) dalam pembelajaran guru belum mengembangkan berbagai keterampilan yang berhubungan dengan interaksi sosial sesama teman atau disebut dengan keterampilan sosial, 5) Selain menerapkan metode Ceramah, guru juga menerapkan kegiatan pembelajaran berkelompok.

Masalah-masalah tersebut berdampak pada aktivitas peserta didik di dalam kelas, antara lain: 1) banyak peserta didik yang kurang tergerak aktif untuk mencari informasi sendiri dari sumber lain, 2) peserta didik cenderung hanya duduk, mendengarkan, dan mencatat apa yang disampaikan oleh guru, 3) peserta didik yang aktif mengemukakan pendapat terbatas pada beberapa anak saja, 4) peserta didik kurang menghargai ketika ada teman yang mengemukakan pendapat, 5) dalam kelompok, banyak ditemukan peserta didik yang hanya menggantungkan diri kepada temannya saat mengerjakan tugas yang diberikan oleh guru, 6) Terbentuknya beberapa kelompok bermain (geng) dalam satu kelas, ada kelompok bermain (geng) yang diam dan ada kelompok bermain (geng) yang vokal (banyak bicara).

Permasalahan-permasalahan di atas, diduga karena guru masih memiliki pemikiran bahwa sumber pembelajaran hanya terpusat pada dirinya. Selain itu guru juga belum terbiasa menerapkan model pembelajaran inovatif yang dapat mengembangkan keterampilan sosial peserta didik selama kegiatan pembelajaran berkelompok. Hal ini terlihat ketika dalam proses pembelajaran guru kurang memberikan bimbingan kepada peserta didiknya.

Dari permasalahan-permasalahan di atas, salah satu masalah yang harus segera diatasi adalah tentang kemampuan peserta didik dalam hal keterampilan yang harus dimiliki peserta didik dalam pembelajaran IPS. Keterampilan Sosial ini relevan untuk dikembangkan dalam pembelajaran IPS, agar kelak para peserta didik dapat hidup sebagai warga masyarakat, warga negara, warga dunia yang dapat berperan dalam masyarakatnya.

Untuk membelajarkan keterampilan Sosial perlu model pembelajaran yang efektif sehingga keterampilan sosial peserta didik dapat meningkat. Pembelajaran yang efektif adalah pembelajaran yang tidak terpusat pada guru saja, melainkan peserta didik juga terlibat aktif dalam kegiatan 
pembelajaran. Terdapat beberapa metode dalam mengajarkan keterampilan sosial kepada para peserta didik melalui IPS, di antaranya adalah pembelajaran Berbasis Proyek (PJBL). ${ }^{3}$ Dengan pembelajaran berdasar proyek, maka pembelajaran IPS tidak semata-mata menghafal konsep, dan pengetahuan yang bersifat kognitif rendah lainnya serta guru sebagai satu-satunya sumber informasi melainkan akan membawa peserta didik untuk berpartisipasi aktif, karena mereka akan diminta melakukan berbagai tugas, seperti bekerja kelompok, berinteraksi dengan teman, mengajukan pendapat selama pembelajaran. Ini berarti bahwa guru bukan satu-satunya yang memberikan informasi karena peserta didik akan mencari sumber yang beragam dan terlibat dalam berbagai kegiatan yang beragam pula. Sedangkan peran guru kecuali bertindak sebagai fasilitator dalam semua kegiatan ini, juga harus mengamati proses pembelajaran untuk memberikan penilaian, tidak hanya untuk perolehan pengetahuan saja tetapi juga menilai keterampilan Sosial peserta didik selama kegiatan pembelajaran berlangsung. Pembelajaran Berbasis Masalah merupakan praktik pedagogis yang dapat meningkatkan sosialisasi dan pembelajaran peserta didik di semua tingkatan umur dan di berbagai level pendidikan, khususnya di tingkat pendidikan Dasar.

Model pemberian proyek termasuk salah satu jenis belajar aktif. Menurut Dewey, model pembelajaran ini dikatakan sebagai model Learning by doing. ${ }^{4}$ Hal ini berarti bahwa proses belajar diperoleh melalui aktivitas atau kegiatan yang dilakukan anak sendiri atau berkelompok, dengan pengertian bagaimana anak melakukan pekerjaan sesuai dengan langkah dan rangkaian tingkah laku tertentu. Diharapkan proses tersebut mampu memberi pengalaman yang berpengetahuan anak, sehingga anak mampu memahami secara lebih dalam karena hal tersebut. Model pembelajaran yang efektif, efisien, serta menyenangkan diharapkan dapat memotivasi peserta didik dalam belajar sehingga aktivitas peserta didik dalam belajar terus meningkat. Model pembelajaran yang efektif, efisien, dan menyenangkan yang akan peneliti terapkan adalah model pembelajaran berbasis proyek (PJBL). Dalam model pembelajaran ini peserta didik dalam kelompok dijamin tidak akan pasif lagi karena masing-masing peserta didik dalam kelompok bersama sama akan memperoleh bertanggung jawab terhadap kasus yang diberikan, sehingga mampu mengolah daya kritis dan memecahkan masalah secara bersama dengan adil. Ciri khas dalam model pembelajaran ini guru menunjuk seorang peserta didik yang mewakili kelompoknya untuk melaporkan hasil kelompok, tanpa memberi tahu terlebih dahulu siapa yang akan mewakili kelompoknya itu. Sehingga masing-masing anggota kelompok harus paham dengan hasil kerja kelompoknya.

Berdasarkan pendapat-pendapat tersebut, maka dapat dikatakan bahwa pendekatan Project Based Learning dikembangkan berdasarkan paham filsafat Konstruktivisme dalam pembelajaran.

\footnotetext{
${ }^{3}$ Nana Supriyatna, dkk, Model Pembelajaran Inovatif (Bandung: Rosda Karya, 2011), 67.

${ }^{4}$ Moeslichatoen. Belajar dan Pembelajaran (Yogyakarta: Rineka Cipta, 2004), 137.
} 
Konstruktivisme mengembangkan atmosfer pembelajaran yang menuntut peserta didik untuk menyusun sendiri pengetahuannya. ${ }^{5}$ Project based learning merupakan pendekatan pembelajaran yang memberikan kebebasan kepada peserta didik untuk merencanakan aktivitas belajar, melaksanakan proyek secara kolaboratif, dan pada akhirnya menghasilkan produk kerja yang dapat dipresentasikan kepada orang lain.

Keunggulan model pembelajaran berbasis proyek ini adalah mengembangkan keterlibatan total setiap individu dalam proses kegiatan pembelajaran. Model pembelajaran ini merupakan model pembelajaran yang berorientasi aktivitas peserta didik dan juga cocok untuk memastikan akuntabilitas individu dalam diskusi/kinerja kelompok, hal ini ditunjukkan adanya kerjasama dalam kelompok dan setiap individu berusaha berpikir untuk menentukan keberhasilan kelompok. Setiap peserta didik mempunyai kesempatan yang sama untuk melakukan yang terbaik untuk kelompok demi mendapatkan nilai maksimun sehingga termotivasi untuk belajar. Setiap peserta didik bekerjasama dan menerima teman-temannya meskipun dari latar belakang yang berbeda. Setiap peserta didik dapat mengembangkan kemampuan mengungkapkan ide atau gagasan dan dapat membandingkannya dengan ide teman-temannya.

Metode Bermain peran (Role playing) adalah salah satu model pembelajaran interaksi sosial yang menyediakan kesempatan kepada murid untuk melakukan kegiatan-kegiatan belajar secara aktif dengan personalisasi. Oleh karena itu, lebih lanjut bentuk pengajaran Role playing memberikan seperangkat/serangkaian situasi-situasi belajar kepada peserta didik dalam bentuk keterlibatan pengalaman sesungguhnya yang dirancang oleh guru. ${ }^{6}$ Selain itu, Role playing sering kali dimaksudkan sebagai suatu bentuk aktivitas dimana pembelajar membayangkan dirinya seolaholah berada di luar kelas dan memainkan peran orang lain saat menggunakan bahasa tutur. ${ }^{7}$ Dapat dikatakan bahwa dalam metode Bermain peran bisa diartikan suatu metode pembelajaran yang menekankan pada aktivitas peserta didik sebaai bentuk proyek yang mengembangkan aspek ketrampilan Sosial peserta didik.

Di dalam era global sekarang pembelajaran IPS dirasa perlu mengalami perubahan, selama ini pembelajaran IPS masih berupa penanaman konsep-konsep dan memberlakukan hafalan kepada para peserta didik. Pembelajaran IPS masa kini sudah semestinya mengikuti berbagai perkembangan yang terjadi di dunia secara global. Pembelajaran IPS seharusnya tidak hanya menekankan pada penguasaan materi semata, melainkan juga membidik pengembangan keterampilan Sosial.

\footnotetext{
${ }^{5}$ Bell, Constructivisme Teaching Learning, 28.

${ }^{6}$ Hamalik ,Strategi Pembelajaran. (Jakarta : Rineka Cipta, 2004) 214.

${ }^{7}$ Syamsu, Tekhnik Proses Pembelajaran. (Jakarta : Rosda Karya, 2000) 142.
} 
Keterampilan Sosial merupakan kemampuan individu untuk berkomunikasi efektif dengan orang lain baik secara verbal maupun non verbal sesuai dengan situasi dan kondisi yang ada pada saat itu. Dalam pengertian ini meliputi kerjasama, dapat berbagi orang lain, partisipasi, berteman, membantu orang lain, menerima segala perbedaan, mampu menjadi pendengar yang baik, komunikasi dan interaksi positif, dapat menghargai diri sendiri dan orang lain, sopan santun, dan berfikiran positif. Keterampilan sosial sangat penting dalam penyesuaian sosial, individu yang memiliki keterampilan yang baik akan memiliki penyesuaian diri yang baik pula, sebaliknya individu yang tidak memiliki penyesuaian diri yang tidak baik akan memiliki keterampilan sosial yang tidak baik pula.

Menurut Ibrahim -dalam bukunya Trianto- keterampilan Sosial atau kooperatif berkembang secara signifikan dalam pembelajaran Kooperatif. Pembelajaran kooperatif sangat tepat digunakan untuk melatihkan keterampilan-keterampilan kerjasama dan kolaborasi, dan juga keterampilanketerampilan tanya-jawab. ${ }^{8}$ Keterampilan sosial yang telah dikembangkan oleh NCSS adalah keterampilan dalam memperoleh informasi, (keterampilan membaca, keterampilan belajar, mencari informasi, dan keterampilan menggunakan alat-alat teknologi), keterampilan yang berkaitan dengan hubungan sosial serta partisipasi dalam masyarakat (keterampilan diri yang sesuai dengan kemampuan dan bakat, bekerja sama, berpartisipasi dalam masyarakat). ${ }^{9}$

Tidak semua anak memiliki keterampilan sosial dan kemampuan menuntaskan tugas-tugas perkembangannya. Salah satu indikator ialah munculnya permasalahan yang dialami anak seperti ingin menang sendiri, sok berkuasa, tidak mau berteman atau memilih-milih teman, bersikap agresif, dan tidak mampu beradaptasi dengan lingkungan. Keterampilan sosial dapat diartikan sebagai kemampuan untuk berinteraksi dengan orang lain pada konteks sosial melalui cara-cara spesifik yang secara sosial diterima atau bernilai dan pada waktu yang sama memiliki keuntungan untuk pribadi dan orang lain. Keterampilan sosial jika ditinjau dari konteks anak sebagai peserta didik di sekolah, adalah kemampuan peserta didik untuk mereaksi secara efektif dan bermanfaat terhadap lingkungan sosial yang merupakan persyaratan bagi penyesuaian sosial yang baik, kehidupan yang memuaskan, dan dapat diterima oleh masyarakat.

Berdasarkan latar belakang yang telah digambarkan di atas, penulis akan mengadakan penelitian dengan judul Pengembangan Perangkat Pembelajaran dengan Pemanfaatan Cerita Rakyat melalui Model Project Based Learning (PJBL) Berbasis Role Playing dalam Meningkatkan Keterampilan Sosial Peserta didik Mata Pelajaran IPS Kelas V.

\footnotetext{
${ }^{8}$ Trianto, Model-Model Terpadu dalam Teori dan Praktek (Jakarta: Prestasi Pustaka Publisher, 2007 ), 45.

${ }^{9}$ Rudy Gunawan, Pengelolaan Pembelajaran (Jakarta : Rineka Cipta, 2011), 67.
} 


\section{METODE PENELITIAN}

Penelitian ini termasuk penelitian Pengembangan (Development research), karena mengembangkan perangkat pembelajaran kelas V semester I dengan topik cerita Sejarah peradaban Indonesia. Hasil pengembangan perangkat berupa Rencana Pelaksanaan Pembelajaran (RPP), Lembar Kerja Peserta didik (LKS), dan Tes Hasil belajar Kognitif, hasil belajar afektif hasil belajar psikomotor. Subjek penelitian adalah peserta didik kelas 5 Madrasah Ibtidaiyah Tuban dengan jumlah peserta didik yang menjadi subyek penelitian ini sebanyak 22 orang yang terdiri dari 10 orang laki-laki dan 12 orang perempuan.

Dalam penelitian ini digunakan rancangan penelitian model pengembangan Four-D Model yang terdiri dari 4 tahap yaitu define (pendefinisian), design (perancangan), develop (pengembangan) dan disseminate (penyebaran) yang dikembangkan oleh Thiagarajan, dkk. Penelitian ini diadaptasi hanya sampai pada tahap develop (pengembangan), sehingga yang telah dikembangkan digunakan pada sekolah yang digunakan sebagai tempat penelitian tanpa disebarkan pada sekolah lain.

Variabel penelitian adalah segala sesuatu yang dijadikan obyek pengamatan dalam penelitian (Arikunto, 2010). Berdasarkan rumusan masalah yang terdapat pada BAB I, maka variabel yang diamati dalam penelitian ini adalah 1) perangkat pembelajaran (RPP, Silabus, LKS dan tes hasil belajar). Dalam penelitian ini, peneliti menggunakan empat teknik pengumpulan data yaitu validasi, observasi, angket, dan tes hasil belajar.

\section{HASIL DAN PEMBAHASAN}

\section{Validitas Silabus}

Berdasarkan analisis data pada Tabel 4.2, instrumen silabus dikategorikan sangat baik dengan alasan instrumen silabus yang berorientasi model Project Based Learning telah valid. Hasil penilaian oleh validator $95 \%$ dari semua komponen silabus sudah valid dan $5 \%$ perlu perbaikan, maka dapat disimpulkan silabus berkategori layak dilanjutkan pada ujicoba. Validitas instrumen ini karena telah divalidasi sesuai ketententuan kelayakan instrumen pembelajaran mengacu ketentuan kelayakan instrumen (Ratumanan dan Laurends, 2011:34). Berdasarkan saran dari validator, dilakukan beberapa perbaikan pada instrumen silabus. Perbaikan yang dilakukan antara lain mengurutkan materi ajar sesuai dengan Kompetensi Dasar dan memperbaiki Kata Kerja Operasional (KKO) yang belum tepat.

\section{Validitas Rencana Pelaksanaan Pembelajaran}

Hasil penilaian oleh validator 95\% dari semua komponen RPP sudah valid dan 5\% perlu perbaikan, maka dapat disimpulkan RPP berkategori layak dilanjutkan pada ujicoba. Perangkat 
dinyatakan valid dan layak karena sesuai dengan kriteria kelayakan yang ditetapkan BNSP (2006) yang artinya perangkat telah terstruktur sesuai ketentuan. Hal ini berarti perangkat pembelajaran telah disusun secara lengkap dan sistematis agar pembelajaran berlangsung secara interaktif, inspiratif, menyenangkan, memotivasi peserta didik untuk berpartisipasi aktif sesuai bakat dan perkembangan fisik serta psikologis peserta didik. Sejalan dengan Piaget yang membagi skema yang digunakan anak untuk memahami dunianya melalui empat periode utama yang berkolerasi dengan pertambahan usia (Dengeng, 2013). Berdasarkan saran dari validator, dilakukan beberapa perbaikan pada instrumen RPP. Perbaikan yang dilakukan antara lain menambahkan indikator yang sesuai dengan KD 4 dan memperbaiki Kata Kerja Operasional (KKO) yang belum tepat.

\section{Validitas Tes Hasil Belajar}

Hasil penilaian dari validator bahwa tes hasil belajar yang dikembangkan oleh peneliti berkategori valid dengan $93,75 \%$ dari validitas isi sudah dapat dipahami dan 6,25\% perlu perbaikan, sedangkan $82,81 \%$ dari validitas bahasa dan penulisan soal sudah dapat dipahami dan $17,19 \%$ perlu perbaikan. Hal ini bisa dilihat pada tabel berikut;

Tabel 1. Validitas Tes Hasil Belajar

\begin{tabular}{|c|c|c|c|c|}
\hline \multirow{2}{*}{ No Soal } & \multicolumn{2}{|c|}{ Validitas Isi } & \multicolumn{2}{c|}{ Validitas Bahasa dan Penulisan Soal } \\
\cline { 2 - 5 } & Nilai & Keterangan & Nilai & Keterangan \\
\hline 1. & 4 & Valid & 4 & Sangat dapat dipahami \\
\hline 2. & 4 & Valid & 3 & Dapat dipahami \\
\hline 3. & 4 & Valid & 3 & Dapat dipahami \\
\hline 4. & 4 & Valid & 3 & Dapat dipahami \\
\hline 5. & 4 & Valid & 3 & Dapat dipahami \\
\hline 6. & 3 & Cukup Valid & 3 & Dapat dipahami \\
\hline 7. & 4 & Valid & 3 & Dapat dipahami \\
\hline 8. & 4 & Valid & 4 & Sangat dapat dipahami \\
\hline 9. & 4 & Valid & 4 & Sangat dapat dipahami \\
\hline 10. & 4 & Valid & 4 & Sangat dapat dipahami \\
\hline 11. & 4 & Valid & 3 & Dapat dipahami \\
\hline 12. & 3 & Cukup Valid & 3 & Dapat dipahami \\
\hline 13. & 4 & Valid & 3 & Dapat dipahami \\
\hline 14. & 3 & Cukup Valid & 3 & Dapat dipahami \\
\hline 15. & 4 & Valid & 4 & Sangat dapat dipahami \\
\hline 16. & 3 & Cukup Valid & 3 & Dapat dipahami \\
\hline Jml & \multicolumn{2}{|c|}{} & & \\
\hline
\end{tabular}

Validitas skor tinggi ini dicapai karena tes hasil belajar berdasarkan pada kesesuaian antara indikator, tujuan, dan rumusan soal, sehingga menunjukkan tes hasil belajar layak untuk diimplementasikan di sekolah. Tes dilakukan dua kali yaitu menggunakan pretest dan posttest 
dilengkapi dengan kisi-kisi yang disusun mengacu pada taksonomi Bloom dan kematangan usia atau teori kognitif Piaget. ${ }^{10}$ (Budiningsih, 2012).

\section{Keterlaksanaan RPP}

Pada Rencana Pelaksanaan Pembelajaran (RPP) terdapat tiga kegiatan yaitu pendahuluan, kegiatan inti, dan kegiatan penutup. Secara keseluruhan dari semua tahap-tahap kegiatan yang ada di dalam RPP menggunakan bahan ajar komik pada ujicoba 2 dilaksanakan baik oleh guru, baik pada pertemuan 1, pertemuan 2, dan pertemuan 3 pada setiap kegiatan pembelajaran. Hal ini terlihat dari skor rata-rata dari pengamat lebih dari 3,0 pada setiap kegiatan pembelajaran. Ratarata keterlaksanaan pembelajaran pada pertemuan 1 adalah 3,64; pada pertemuan 2 adalah 3,5; dan pada pertemuan 3 adalah 3,64. Hasil pengamatan keterlaksanaan RPP mendapat skor keterlaksanaan dalam kategori reliabel sebesar 98\%. Reliabilitas ini menunjukkan kemantapan apabila RPP ini diujikan lagi dengan perangkat yang sama akan mendapatkan hasil yang relatif sama. Hal ini bisa dilihat pada tabel berikut;

Tabel 2. Keterlaksanaan RPP

\begin{tabular}{|c|c|c|c|c|c|c|c|}
\hline \multirow[t]{2}{*}{ No } & \multirow{2}{*}{$\begin{array}{c}\text { Kegiatan } \\
\text { Pembelajaran }\end{array}$} & \multicolumn{2}{|c|}{ RPP 1} & \multicolumn{2}{|c|}{ RPP 2} & \multicolumn{2}{|c|}{ RPP 3} \\
\hline & & P1 & P2 & P1 & $\mathbf{P 2}$ & P1 & $\mathbf{P 2}$ \\
\hline 1 & Pendahuluan (1) & 3 & 4 & 3 & 4 & 3 & 4 \\
\hline 2 & Pendahuluan (2) & 3 & 4 & 3 & 3 & 4 & 4 \\
\hline 3 & Fase Read & 4 & 4 & 4 & 3 & 4 & 3 \\
\hline 4 & Fase Question (1) & 3 & 3 & 3 & 4 & 3 & 4 \\
\hline 5 & Fase Question (2) & 4 & 4 & 4 & 3 & 4 & 3 \\
\hline 6 & Fase Summary & 4 & 4 & 3 & 4 & 4 & 3 \\
\hline 7 & Penutup & 3 & 3 & 3 & 4 & 3 & 4 \\
\hline & Jumlah & 25 & 26 & 24 & 25 & 26 & 25 \\
\hline & Rata-rata Skor & \multicolumn{2}{|c|}{3,64} & \multicolumn{2}{|c|}{$\mathbf{3 , 5}$} & \multicolumn{2}{|c|}{3,64} \\
\hline & Reliabilitas & & & & & & \\
\hline \multicolumn{2}{|c|}{ Rata-rata Reliabilitas } & \multicolumn{6}{|c|}{$98 \%$} \\
\hline
\end{tabular}

Keterlaksanaan pembelajaran dilaksanakan baik oleh guru, hal ini dikarenakan beberapa hal antara lain pembelajaran merupakan implementasi RPP yakni pelaksanaan pembelajaran meliputi kegiatan pendahuluan, kegiatan inti, dan kegiatan penutup. Tahap pelaksanaan pembelajaran mengikuti skenario tahap-tahap strategi pembelajaran menggunakan model Project Based learning. Hal ini sesuai dengan yang dikemukakan oleh Slavin dengan konsep pemagangan kognitif yaitu seseorang yang sedang belajar secara tahap demi tahap memperoleh keahlian dalam interaksinya dengan seorang pakar. ${ }^{11}$ Pernyataan ini juga sejalan dengan hasil pengamatan

\footnotetext{
${ }^{10}$ Asri Budiningsih,. Belajar dan Pembelajaran. (Jakarta: Rineka Cipta, 2011) 56.

${ }^{11}$ Robert E. Slavin,. Psikologi Pendidikan: Teori dan Praktik. (Jakarta: Indeks,2008), 54.
} 
keterlaksanaan pembelajaran, pengamat menyatakan bahwa langkah-langkah pembelajaran yang tertuang dalam RPP terlaksana $100 \%$.

Pada kegiatan pendahuluan, guru menyampaikan apersepsi kepada peserta didik dan menyampaikan secara garis besar tujuan pembelajaran yang hendak dicapai. Selanjutnya adalah kegiatan inti merupakan proses pembelajaran untuk mencapai $\mathrm{KD}$ yang dilakukan secara interaktif, inspiratif, menyenangkan, menantang, memotivasi peserta didik untuk berpartisipasi aktif, serta memberikan ruang yang cukup sesuai bakat, minat, dan perkembangan fisik peserta didik. Kegiatan inti menggunakan model pembelajaran Project Based learning yang disesuaikan dengan karakteristik peserta didik dan mata pelajaran.

\section{Hambatan dalam Proses Pembelajaran}

Dalam proses pelaksanaan penelitian, guru mengalami beberapa hambatan antara lain peserta didik belum terbiasa menggunakan Model pembelajaran Project Based Learning dalam pembelajaran, guru kesulitan pengkondisian waktu dalam pembelajaran, beberapa peserta didik terlihat bermain sendiri setelah melakukan proses Read pada bahan ajar komik, dan selama pembelajaran beberapa peserta didik masih menggunakan bahasa daerah. Hambatan-hambatan tersebut mampu diatasi baik oleh guru dalam proses pembelajaran dengan beberapa solusi antara lain guru menjelaskan proses pembelajaran menggunakan Project Based Learning, guru melakukan pembagian waktu tiap-tiap kegiatan dalam pembelajaran, sebaiknya peserta didik yang telah selesai melakukan proses Read pada bahan ajar cerita, melakukan pembacaan ulang pada halaman-halaman tertentu yang berisi materi-materi pembelajaran, dan lebih membiasakan peserta didik berkomunikasi menggunakan bahasa Indonesia.

\section{Respon Peserta didik}

Berdasarkan analisis angket respon peserta didik dapat diketahui bahwa pembelajaran yang diterapkan dikelas memperoleh persentase respon positif peserta didik yang menjawab "Ya" sebanyak 95\% dan persentase respon negatif peserta didik yang menjawab "Tidak" sebesar 5\%. Berdasarkan hasil data tersebut menunjukkan bahwa sebagian besar peserta didik memberikan respon positif. Tingginya respon positif peserta didik untuk mengikuti pembelajaran menggunakan strategi pembelajaran Role playing dikarenakan beberapa hal antara lain karena rasa ingin tahu, dan langkah dalam pembelajaran berkaitan erat dengan kehidupan sehari-hari peserta didik yaitu mengungkapkan materi dengan gaya bahasa peserta didik itu sendiri bersama teman untuk memahami konsep yang mereka pelajari (Miller, 2008). Hal ini berarti peserta didik merasa senang terhadap pembelajaran hari ini mengenai materi pelajaran, bahan ajar komik, suasana belajar, dan cara guru mengajar. Peserta didik mudah memahami materi pada bahan ajar cerita rakyat dengan menggunakan model pembelajaran Project Based Learning. Peserta didik 
tertarik dan memahami bahasa, penampilan, dan gambar-gambar pada bahan ajar komik. Peserta didik sangat berminat jika pembelajaran menggunakan metode Cerita rakyat dan menggunakan model pembelajaran Project Based learning (PjBL) pada kegiatan pembelajaran berikutnya. Hal ini bisa dilihat pada tabel berikut;

Tabel 3. ??

\begin{tabular}{|c|c|c|c|}
\hline \multirow[t]{2}{*}{ No } & \multirow[t]{2}{*}{ Pertanyaan } & \multicolumn{2}{|c|}{$\begin{array}{l}\text { Jumlah Peserta didik yang } \\
\text { Menjawab } \\
\end{array}$} \\
\hline & & Ya & Tidak \\
\hline \multirow[t]{5}{*}{1} & $\begin{array}{l}\text { Apakah kalian merasa senang terhadap pembelajaran hari } \\
\text { ini mengenai komponen berikut: }\end{array}$ & & \\
\hline & a. Materi pelajaran & 10 & 0 \\
\hline & b. Bahan ajar komik & 10 & 0 \\
\hline & c. Suasana belajar & 10 & 0 \\
\hline & d. Cara guru mengajar & 9 & 1 \\
\hline \multirow[t]{4}{*}{2} & $\begin{array}{l}\text { Apakah kalian mudah memahami materi pada bahan cerita } \\
\text { rakyat dengan menggunakan Model Pembelajaran PjBL } \\
\text { (Project Based Learning)? }\end{array}$ & & \\
\hline & a. Membaca bahan ajar cerita rakyat & 9 & 1 \\
\hline & b. Membuat pertanyaan dari bahan ajar cerita rakyat & 9 & 1 \\
\hline & $\begin{array}{l}\text { c. Membuat rangkuman setelah membaca bahan ajar cerita } \\
\text { rakyat }\end{array}$ & 8 & 2 \\
\hline \multirow[t]{4}{*}{3} & Apakah kalian tertarik dan memahami? & & \\
\hline & a. Bahasa yang digunakan pada bahan ajar cerita rakyat & 10 & 0 \\
\hline & b. Penampilan bahan ajar cerita rakyat. & 10 & 0 \\
\hline & c. Gambar-gambar pada bahan ajar cerita rakyat & 10 & 0 \\
\hline 4 & $\begin{array}{l}\text { Apakah kalian merasa mudah menjawab butir soal (THB } \\
\text { Kognitif) setelah mengikuti pembelajaran menggunakan } \\
\text { bahan ajar cerita rakyat? }\end{array}$ & 10 & 0 \\
\hline 5 & $\begin{array}{l}\text { Apakah kalian berminat untuk mengikuti kegiatan } \\
\text { pembelajaran berikutnya seperti yang telah kalian ikuti? }\end{array}$ & 9 & 1 \\
\hline \multicolumn{2}{|r|}{ Jumlah } & 114 & 6 \\
\hline \multicolumn{2}{|r|}{ Persentase } & $95 \%$ & $5 \%$ \\
\hline
\end{tabular}

Secara keseluruhan, peserta didik memberikan respon positif terhadap pembelajaran. Respon positif peserta didik menunjukkan bahwa peserta didik antusias dengan pembelajaran yang disajikan. Hal ini dapat memotivasi peserta didik untuk meningkatkan perhatian dan membuat mereka terlibat dalam pengalaman pembelajaran yang menyenangkan dan bermakna (Nur, M. 2010).

\section{Hasil Belajar}

Berdasarkan tes hasil belajar kognitif peserta didik mengalamai peningkatan. Penilaian ranah kognitif pretest pada ujicoba 2 di kelas IV-B peserta didik yang tuntas secara individu 3 
peserta didik dan 19 peserta didik tidak tuntas dengan rata-rata kelas 58,8. Proporsi ketuntasan yang dicapai peserta didik paling rendah 50 dan paling tinggi 75 . Sedangkan ketuntasan klasikal pretest tidak tuntas dengan persentase 13,6\%. Sedangkan posttest pada ujicoba 2 di kelas IV-B semua peserta didik tuntas secara individu dengan rata-rata kelas 95,17. Proporsi ketuntasan yang dicapai peserta didik paling rendah 81,25 dan paling tinggi 100 . Secara individual dan klasikal posttest mencapai ketuntasan $100 \%$. Hal ini bisa dilihat pada tabel berikut;

Tabel 4. Hasil Belajar

\begin{tabular}{|c|c|c|c|c|c|}
\hline \multirow{3}{*}{ No } & \multirow{3}{*}{$\begin{array}{c}\text { Inisial } \\
\text { Peserta } \\
\text { didik }\end{array}$} & \multicolumn{4}{|c|}{ Hasil Ujicoba 2} \\
\hline & & \multicolumn{2}{|c|}{ Pretest } & \multicolumn{2}{|c|}{ Posttest } \\
\hline & & Proporsi & Ket & Proporsi & Ket \\
\hline 1 & AADP & 50 & TT & 100 & $\mathrm{~T}$ \\
\hline 2 & AAIS & 50 & TT & 87,5 & $\mathrm{~T}$ \\
\hline 3 & AAMA & 75 & $\mathrm{~T}$ & 100 & $\mathrm{~T}$ \\
\hline 4 & AEAI & 62,5 & TT & 100 & $\mathrm{~T}$ \\
\hline 5 & BAS & 50 & TT & 93,75 & $\mathrm{~T}$ \\
\hline 6 & FRF & 56,25 & TT & 100 & $\mathrm{~T}$ \\
\hline 7 & KDAA & 56,25 & TT & 93,75 & $\mathrm{~T}$ \\
\hline 8 & MAS & 68,5 & TT & 100 & $\mathrm{~T}$ \\
\hline 9 & MDB & 75 & $\mathrm{~T}$ & 100 & $\mathrm{~T}$ \\
\hline 10 & MDW & 62,5 & TT & 81,25 & $\mathrm{~T}$ \\
\hline 11 & MRF & 50 & TT & 100 & $\mathrm{~T}$ \\
\hline 12 & MRA & 56,25 & TT & 100 & $\mathrm{~T}$ \\
\hline 13 & NDS & 62,5 & TT & 100 & $\mathrm{~T}$ \\
\hline 14 & NFZS & 50 & TT & 100 & $\mathrm{~T}$ \\
\hline 15 & PYRW & 50 & TT & 93,75 & $\mathrm{~T}$ \\
\hline 16 & RAKT & 50 & TT & 100 & $\mathrm{~T}$ \\
\hline 17 & RRS & 68,5 & TT & 93,75 & $\mathrm{~T}$ \\
\hline 18 & SNV & 75 & $\mathrm{~T}$ & 100 & $\mathrm{~T}$ \\
\hline 19 & TAS & 62,5 & TT & 100 & $\mathrm{~T}$ \\
\hline 20 & TJN & 50 & TT & 100 & $\mathrm{~T}$ \\
\hline 21 & TNM & 56,25 & TT & 93,75 & $\mathrm{~T}$ \\
\hline 22 & NDS & 56,25 & TT & 100 & $\mathrm{~T}$ \\
\hline \multicolumn{2}{|c|}{ Rata-rata } & \multicolumn{2}{|c|}{58,8} & \multicolumn{2}{|c|}{97,2} \\
\hline \multicolumn{2}{|c|}{$\begin{array}{c}\text { Ketuntasan } \\
\text { Klasikal }\end{array}$} & \multicolumn{2}{|c|}{$\begin{array}{c}13,6 \% \\
\text { (Tidak Tuntas) }\end{array}$} & \multicolumn{2}{|c|}{$\begin{array}{c}100 \% \\
\text { (Tuntas) }\end{array}$} \\
\hline
\end{tabular}

Untuk ranah afektif peserta didik pertemuan 1 pada ujicoba 2 di kelas IV-B semua peserta didik tuntas secara individu dengan rata-rata kelas 90,32. Proporsi ketuntasan yang dicapai peserta didik paling rendah 79 dan paling tinggi 96. Sedangkan ketuntasan klasikal penilaian afektif pertemuan 1 tuntas dengan persentase 100\%. Pada pertemuan 2 pada ujicoba 2 di kelas IV-B semua peserta didik tuntas secara individu dengan rata-rata kelas 90,1. Proporsi ketuntasan yang dicapai peserta didik paling rendah 79 dan paling tinggi 96. Sedangkan ketuntasan klasikal penilaian afektif 
pertemuan 2 tuntas dengan persentase 100\%. Pada pertemuan 3 pada ujicoba 2 di kelas IV-B semua peserta didik tuntas secara individu dengan rata-rata kelas 91,41. Proporsi ketuntasan yang dicapai peserta didik paling rendah 79 dan paling tinggi 96. Sedangkan ketuntasan klasikal penilaian afektif pertemuan 3 tuntas dengan persentase 100\%. Berdasarkan data tersebut dapat diketahui bahwa hasil penilaian afektif mengalami peningkatan pada tiap pertemuan. Hal ini bisa dilihat pada tabel berikut;

Tabel 5. Tabel Penilaian Afektif

\begin{tabular}{|l|c|c|c|}
\hline \multirow{2}{*}{ Aspek } & \multicolumn{3}{|c|}{ Ujicoba 2 } \\
\cline { 2 - 4 } & Pertemuan 1 & Pertemuan 2 & Pertemuan 3 \\
\hline Ketuntasan Individual & $91,2(\mathrm{~T})$ & $91,4(\mathrm{~T})$ & $92,5(\mathrm{~T})$ \\
\hline Ketuntasan Klasikal & $100 \%(\mathrm{~T})$ & $100 \%(\mathrm{~T})$ & $100 \%(\mathrm{~T})$ \\
\hline
\end{tabular}

Keterlaksanaan pembelajaran tidak akan berjalan dengan baik tanpa didukung dengan perangkat pembelajaran yang baik. Perangkat pembelajaran meliputi silabus dan RPP, dan bahan ajar. RPP yang digunakan harus sesuai dengan fase-fase Model Pembelajaran PjBL (Project Based Learning) dengan menggunakan bahan cerita rakyat. Bahan ajar komik merupakan bentuk komunikasi yang membawa peserta didik ke dalam pemahaman-pemahaman baru. Melalui interaksi dan dialog antar tokoh, secara tidak langsung peserta didik dapat merasakan peranan tokoh dan peristiwa yang sedang terjadi dalam alur cerita komik tersebut, sehingga informasi bisa tersampaikan. Hal ini sesuai dengan pendapat Maharsi (2011:4) komik adalah gambar-gambar dan lambang-lambang yang berdekatan bersebelahan dalam urutan waktu tertentu yang bertujuan untuk memberikan informasi. Penggunaan komik dalam pembelajaran akan lebih baik jika dipadukan dengan strategi belajar mengajar yang sesuai, sehingga komik dapat menjadi alat pengajaran yang efektif. Dalam hal ini pembelajaran dilakukan menggunakan model Pembelajaran PjBL (Project Based Learning) yang membuat peserta didik sangat aktif ketika mengikuti proses pembelajaran.

Penelitian ini juga sesuai dengan penelitian yang dilakukan oleh Hanif Fikri (2013) yang berujuan untuk mengembangkan buku komik suplemen dalam pembelajaran menulis narasi pada Sekolah Dasar. Penelitian tersebut membuktikan bahwa buku komik bisa meningkatkan hasil belajar peserta didik dalam pembelajaran menulis narasi pada Sekolah Dasar. Hasil penelitian ini sesuai dengan pendapat serta teori-teori yang mendukung. Teori belajar Bruner menyarankan agar seorang guru tidak hanya memikirkan bagaimana peserta didik belajar tetapi juga bagaimana cara membantu peserta didik untuk belajar yang terbaik. Hal ini sesuai dengan pendapat Budiningsih bahwa proses belajar akan berjalan dengan baik jika guru memberikan kesempatan kepada peserta didik untuk menemukan suatu konsep dan pemahaman melalui contoh-contoh yang dijumpai dalam 
kehidupannya. Dalam penelitian ini peserta didik menemukan konsep-konsep materi yang ada pada bahan ajar komik dengan alur cerita yang bisa mereka jumpai dalam kehidupan sebenarnya. ${ }^{12}$

Sedangkan menurut teori Piaget bahwa struktur kognitif yang sudah dimiliki seseorang harus disesuaikan dengan informasi yang diterima. Di dalam kelas, anak- anak diberi peluang untuk saling berbicara dan diskusi dengan teman- temannya. ${ }^{13}$

Berdasarkan implikasi teori Kontruksivisme, pembelajaran yang dirancang dengan matang memiliki dampak sebagai bahan dengan bentuk penyajian baru, namun memberikan ketertarikan yang baik bagi peserta didik.

\section{PENUTUP}

\section{Simpulan}

Berdasarkan hasil Penelitian ini menyimpulkan bahwa bahan ajar komik beserta perangkat pembelajaran pendukungnya yang dikembangkan menurut kebenaran konsep materi, bahasa dan gambar pada topik bagian tubuh tumbuhan dan fungsinya melalui model pembelajaran $\mathrm{PjBL}$ (Project Based Learning) layak, praktis dan efektif untuk meningkatkan hasil belajar peserta didik. Hal ini dibuktikan dengan hasil terlaksananya fase pembelajaran yang baik oleh guru, hasil belajar peserta didik mencapai ketuntasan secara individu dan klasikal, dan respon peserta didik yang sangat baik.

Dalam proses pelaksanaan penelitian, guru mengalami beberapa hambatan antara lain peserta didik belum terbiasa menggunakan model pembelajaran PjBL (Project Based Learning) dalam pembelajaran, guru kesulitan pengkondisian waktu dalam pembelajaran, beberapa peserta didik terlihat bermain sendiri setelah melakukan proses Read pada bahan ajar komik, dan selama pembelajaran beberapa peserta didik masih menggunakan bahasa daerah. Hambatan-hambatan tersebut mampu diatasi guru dalam proses pembelajaran dengan beberapa solusi antara lain guru menjelaskan proses pembelajaran menggunakan model pembelajaran PjBL (Project Based Learning), guru melakukan pembagian waktu tiap-tiap kegiatan dalam pembelajaran, sebaiknya peserta didik yang telah selesai melakukan proses Read pada bahan ajar komik, melakukan pembacaan ulang pada halaman-halaman tertentu yang berisi materi-materi pembelajaran, dan lebih membiasakan peserta didik berkomunikasi menggunakan bahasa Indonesia.

\section{Saran}

Berdasarkan simpulan dan beberapa temuan, maka peneliti dapat mengemukakan beberapa saran. Pertama, bahan ajar komik yang dikembangkan dapat dijadikan buku pendamping IPS

\footnotetext{
${ }^{12}$ Asri Budiningsih,. Belajar dan Pembelajaran. (Jakarta: Rineka Cipta, 2012), 41.
}

${ }^{13}$ Ibid., 35. 
peserta didik kelas V Sekolah Dasar ketika mempelajari materi bagian tubuh tumbuhan dan fungsinya. Kedua, bahan ajar komik yang dikembangkan dalam penelitian dapat digunakan oleh pendidik (guru) sebagai buku tambahan dalam pembelajaran IPS materi cerita rakyat di Indonesia, agar pembelajaran IPS terasa menyenangkan. Ketiga, bahan ajar komik yang dikembangkan dalam penelitian ini dapat dijadikan sebagai referensi dalam menghasilkan komik-komik lain untuk alat pembelajaran. Keempat, pada pembelajaran memerlukan persiapan yang matang dan pengelolaan waktu yang optimal untuk setiap fase kegiatan menggunakan model pembelajaran PjBL (Project Based Learning), sehingga semua peserta didik aktif dalam pembelajaran

\section{DAFTAR PUSTAKA}

Akbar, Sa'dun. 2013. Instrumen Perangkat Pembelajaran. Bandung: Remaja Rosdakarya.

Amminudin. 2013. Pengantar Apresiasi Sastra. Bandung: Sinar Baru Algensindo.

Anderson and Krathwohl. 2010. Kerangka Landasan untuk Pembelajaran, Pengajaran, dan Asesmen. Yogyakarta: Pustaka Pelajar.

Arends, Richard. 2012. Learning to Teach. New York: McGraw-Hill.

Arsyad, Ashar. 2006. Media Pembelajaran. Jakarta: Raja Grafindo Persada.

Arikunto, Suharsismi. 2010. Prosedur Penelitian Suatu Pendekatan Praktik. Jakarta: Rineka Cipta Atinah, Sri. 2011. Strategi Pembelajaran di SD. Jakarta: Universitas Terbuka.

BNSP. 2006. Standar Kompetensi dan Kompetensi Dasar Sekolah Menengah Pertama (IPA). Jakarta; Depdiknas.

Budiningsih, Asri. 2012. Belajar dan Pembelajaran. Jakarta: Rineka Cipta.

Dengeng, I Nyoman Sudana. 2003. Ilmu Pembelajaran: Klasifikasi Variabel untuk Pengembang Teori dan Penelitian. Bandung: Arasmedia.

Dimyati dan Mudjiono. 2002. Belajar dan Pembelajaran. Jakarta: Rineka Cipta.

Fikri, Hanif. 2015. Pengembangan Buku Suplemen Komik dalam Pembelajaran Menulis Narasi dengan Menggunakan Model Picture and Picture Pada Peserta didik Kelas IV Sekolah Dasar. Makalah Komprehenshif Tesis tidak diterbitkan. Surabaya: Program Pascasarjana Unesa

Holladay, Jennifer. 2013. "The Character of Our Content: A Parent Confronts Bias in Early Elementary Literature”. Journal Articles. Vol 27 No.2.

Howe, A,C. And Jones, L. 1993. Engaging Children in Science. N. Y: Merill.

Iskandarwassid. 2013. Strategi Pembelajaran Bahasa. Bandung: PT Remaja Rosdakarya

Muslich, Masnur. 2010. Text Book Writing (Dasar-Dasar Pemahaman Penulisan, dan Pemaknaan Buku Teks). Jogjakarta: Ar-ruzz Media. 
Nagata, Ryoichi. 1999. "Learning Biochemistry through Manga Helping Students Learn and Remember, and Making Lectures More Exciting”. Journal Articles. Vol 27 No.4.

Nu'man Somantri, Muhammad. 2001. Menggagas Pembaharuan Pendidikan IPS. Bandung: Remaja Rosdakarya

Nurgiyantoro, Burhan. 2007. Teori Pengkajian Fiksi. Yogyakarta: Gadjah Mada University Press.

Sabar Nurochman. 2007. Pendekatan Project Based Learning Sebagai Upaya Internalisasi Scientific Method Bagi Mahapeserta didik Calon Guru Fisika. FMIPA Universitas Negeri Yogyakaarta.

Slavin, Robert E. (2008). Psikologi Pendidikan: Teori dan Praktik. Jakarta: PT Indeks.

Sudjana, Nana dan Ahmad Rivai. (2010). Media Pengajaran. Bandung: Sinar Baru Algensindo.

Sudjana, Nana. (2005). Dasar-Dasar Proses Belajar Mengajar. Bandung: Sinar Baru Algensindo.

Sugiyono. (2008). Metode Penelitian Pendidikan Pendekatan Kuantitatif, Kualitatif, dan R\&D. Bandung: Alfabeta.

Sunendar \& Iskandarwassid. (2013). Strategi Pembelajaran Bahasa. Bandung: PT Remaja Rosdakarya.

Trianto, (2007). Model Pembelajaran Terpadu dalam Tepri dan Praktek. Jakarta: Prestasi Pustaka publisher.

Wahab, Abdul Aziz. 2007. Metode dan Model-Model Mengajar Ilmu Pengetahuan Sosial (IPS). Bandung: Penerbit Alfabeta

Woolfolk, Anita. 2009. Educational Psycology. Yogyakarta: Pustaka Pelajar.

Wrigley, H.S. 1998. "Knowledge in Action: The Promise of Project-Based Learning". dalam http://repository.upi.edu/operator/uploads/s diakses pada tanggal $10 \mathrm{Juli} 2007$. 